\title{
THE UNIVERSITY OF HEIDELBERG AND THE JEWS: FOUNDING AND FINANCING THE NEEDS \\ OF A NEW UNIVERSITY
}

Jürgen Miethke

Founding a university in the later Middle Ages was a difficult task. Yet the main problem did not lie in knowing how an institution of higher learning might look. Since the thirteenth century, there had been sufficient models in the prestigious universities of Bologna, Paris and Oxford, which could be imitated and ameliorated in the planning of a new institution in a new location. Moreover, the act of founding an institution was not at all unusual in those times, as acts of foundation in imitation of the successful models of the ancient studia ex consuetudine had been enacted since the thirteenth century; indeed, almost since the time these universities had begun. Bologna, Paris and Oxford had all formed their structures in the early thirteenth century; the first studia ex privilegio, which were founded by a charter of foundation came into being in the third decade of the thirteenth century: 1222 (Padua), 1224 (Naples), and 1229 (Toulouse), to mention only those foundations which have survived. The studia ex consuetudine and these studia ex privilegio were almost equal in age, and they were not treated differently during the medieval period with regard to the degrees they conferred or the reputation they held.

Neither the medieval Holy Roman Empire nor the Roman king erected any studium or universitas north of the Alps before the middle of the fourteenth century. There were enough opportunities for intellectual adventures on the part of German clerics and young noblemen, who hurried to Paris or to the universities of the northern part of Italy (Reichsitalien). It was only the then still-disputed king of the Romans Charles IV, elected in 1346 in opposition to the Roman emperor Louis the Bavarian, who managed to start a university in Prague in 1347/1348, (though it really came to life only some years or decades later). ${ }^{1}$ But this

* This essay is published as it was pronounced at the conference in Madison, Wisconsin. Only the most necessary notes are added. A stylistic overview of the English has kindly been done by Eric Goddard, Spencer Young and William Courtenay. But of course all failures and slips in thought or expression must rest on my account. 
foundation provided (so to speak) an impetus to the competitive efforts of different German princes and towns in bringing universities to life. The neighboring regions were also stimulated in this race. By the end of the fourteenth century there were several different universities founded in central Europe: in Vienna (1365/1384), Kraków (1363/1364 1397/1400), Heidelberg (1385/1386), Cologne (1388), and Erfurt (1382/1392), to name only those which were most highly reputed. There was, it seems, a whole "wave" of foundations which considerably condensed the network of universities in Europe.

This is a story of success - of successfully developing a model of higher learning and adjusting it to developing needs. The foundation of universities seems to be a matter of politics, which could be considered almost as a normal instrument of governmental decisions. But if we look a little more carefully into the matter we can detect a more complicated history. The founding of a new university was by no means an instant success; it required a great deal of management and constant nurturing in order to make the original intentions a successful reality. We cannot dwell here in abstract terms on the presuppositions of the founding of universities in fourteenth-century Europe. Rather, I will here examine my own university, Heidelberg, presently the oldest university in Germany, founded in 1385/1386. We celebrated the six-hundredth anniversary of this university some twenty years ago with a huge series of festivities. Many papers were written on the history of this site of higher education. But today I want to look specifically at the needs which were not so easy to meet when the venture of establishing a new university was first embarked upon.

We know the time and place of this final decision. Marsilius of Inghen, a Parisian professor in the Faculty of Arts and the main counsellor of the prince Elector of the Palatinate throughout the entire process of founding the University of Heidelberg, left a short report, based on his memory, some months after the events in question. ${ }^{2}$ This

\footnotetext{
1 See Peter Moraw, "Prag. Die älteste Universität in Mitteleuropa," in Stätten des Geistes, ed. Alexander Demandt (Cologne, 1999), pp. 127-46; now slightly reworked in Moraw, Gesammelte Beiträge zur deutschen und europäischen Universitätsgeschichte, Strukturen - Personen - Entwicklungen, Education and Society in the Middle Ages and Renaissance 31 (Leiden, 2008), pp. 79-100, esp. pp. 87-92 (look, for instance, also at pp. 121-22). More optimistic in respect to the first decades of the university of Prague is František Šmahel, "Die Anfänge der Prager Universität, Kritische Reflexionen zum Jubiläum eines 'nationalen Monuments',” Historica SN 3-4 (1996-1997), 7-50, now: Šmahel, Die Prager Universität im Mittelalter /The Charles University in the Middle Ages, Gesammelte Aufsätze, Education and Society in the Middle Ages and Renaissance 28 (Leiden, 2007), pp. 3-50, esp. pp. 22-30.

2 Acta universitatis Heidelbergensis, 1 (simul Acta facultatis iuridicae, 1) = Die Rektorbücher der Universität Heidelberg, 1 (1386-1410), ed. Jürgen Miethke,
} 
report is by no means a complete story. It is meant as an ideal normative report of the conditions under which a new university was founded, written down in the rector's book (Amtsbuch) to fix in memory the important facts and, especially, the important decisions that would impact university affairs in the future. ${ }^{3}$ Here, we are told that the Count Palatine Ruprecht I had assembled his council in the castle of Wersau (a no longer extant castle near Mannheim) in order to decide what to do with the privilege presented by a special papal legate, a scribe of the papal court named Petrus de Coppa, ${ }^{4}$ which was secured at a high cost in Genoa at the papal court of the "Roman" pope Urban VI some months before. ${ }^{5}$

Here we learn that in the eyes of Marsilius and, obviously, in the eyes of the prince Palatinate as well, the reception of the papal privilege did not yet mean that the final decision regarding the founding of the University of Heidelberg had been made. The count and his staff still had to decide what to do in Heidelberg. We do not know who was present at the assembly of Wersau. Nor do we know what arguments were used in favor of or against the foundation of the university. We are only informed that the council at this moment gave the green light to all necessary acts, which were then followed step-by-step. First, Marsilius was nominated as the special delegate of the count to oversee all necessary acts, receiving a lavish remuneration in personal income from Palatinate taxes

curantibus Heiner Lutzmann, Hermann Weisert, vol. 2, curante Heiner Lutzmann, Libri actorum Universitatis Heidelbergensis / Die Amtsbücher der Universität Heidelberg, A 1-2 (Heidelberg, 1986-1999; resp. 2001-2003), 1:146-49, nos. 72-73.

${ }^{3}$ Ibid, 1:146-7: "Ut modus incepcionis dicti studii universis posteris innotescat utque statuta que incepta et acta sunt pro eius bono regimine et ad que tenenda constringuntur et constringentur magistri presentes pariter et futuri in quacumque facultate fuerint magistrati, insuper scolares ea sub compendio presenti libro duxi inscribenda, ne forte per ignoranciam eorum aliquis ipsis vel alicui ex eis contravenire presumat ...”

${ }^{4}$ Frank Rexroth, Deutsche Universitätsstiftungen von Prag bis Köln, Beihefte zum Archiv für Kulturgeschichte 34 (Cologne, 1992), p. 174, note 6.

5 The so-called founding charter (1385 oct. 23), printed in: Urkundenbuch der Universität Heidelberg, ed. Eduard Winkelmann, 1: Urkunden; 2: Regesten (Heidelberg 1886), pp. 3-4, no. 2; separately, too, ed. Jürgen Miethke, “Heidelberg 1385/86," in Charters of Foundation and Early Documents of the Universities of the COIMBRAGroup, eds. Jos. M. M. Hermans and Marc Nelissen (Groningen, 1994), pp. 38, 99-100; and the second, revised edition (Leuven, 2005), pp. 56-57, 126. The function of such charters has been studied in Jürgen Miethke, "Päpstliche Universitätsgründungsprivilegien und der Begriff eines Studium generale im RömischDeutschen Reich des 14. Jahrhunderts,” in Zwischen Wissenschaft und Politik, Studien zur deutschen Universitätsgeschichte, Festschrift für Eike Wolgast zum 65. Geburtstag, eds. Armin Kohnle, Frank Engehausen (Stuttgart, 2001), pp. 1-10 [repr. in: Miethke, Studieren an mittelalterlichen Universitäten: Chancen und Risiken. Gesammelte Aufsätze, Education and Society in the Middle Ages and Renaissance 19 (Leiden, 2004), pp. 1-12]. 
(herbesture) on the city of Heidelberg. ${ }^{6}$ The successor of the Count Palatine Ruprecht I, his nephew Ruprecht II, would later succinctly describe in his final testament the efforts of his predecessor: "a university in our city Heidelberg, which our uncle duke Ruprecht I of blessed memory has acquired by great entreaty from our Holy Father the pope and the Apostolic See in Rome and has upheld it with great expense and much labor and has bequeathed it to us."7

Indeed, the oldest administrative books of the new university are filled with records of special activities, which the count and the professors undertook in order to consolidate the internal vitality of the new university and to help the community of scholars to live together peacefully in the city along with the citizens, who were not accustomed to the new, youthful group of scholars. ${ }^{8}$ They presented the new institution to the public in the medieval form of privileges. Let us take a brief look at some of these activities, without claiming to be comprehensive. First there were the six privileges, which were obviously formulated by Marsilius of Inghen himself (perhaps together with some other professors) and which were issued on October $1,1386 .{ }^{9}$ These were the first official documents which would later be held in high esteem throughout almost the whole history of the university to come. They were lost (with one exception) only at the end of the Second World War in 1945. Here, the legal framework of the university was laid down, in very close imitation of the circumstances fitted to the University of Paris, although the tiny city of Heidelberg, which at that time only had about 3,000 to 5,000 inhabitants, was not at all similar to that late medieval European metropolis.

But the labor of the men in charge of getting the university to work and bring it to life remained conspicuous. Immediately after getting the privileges from the Count Palatine, the university commenced its

\footnotetext{
${ }^{6}$ Urkundenbuch (as in n. 5) 1:4-5, no. 3.

${ }^{7}$ Urkundenbuch 1:61-62, no. 39 [1395 July 13]: “das studium und schule zu heidelberg in unßer statt, das unser vetter hertzog Ruprecht der alte seliger gedächtnus von unserm heiligen Vatter dem papst und dem stul von rom mit großer bitt erworben und mit großer kost und arbeit bisher gehalten und auf unß gebracht hat."

${ }^{8}$ See also the overview by Matthias Nuding, "Die Universität, der Hof und die Stadt um die Wende zum 15. Jahrhundert: Fragen an die ältesten Heidelberger Rektoratsakten,” Zeitschrift für die Geschichte des Oberrheins 146 [NF 107] (1998), 197-248.

9 The university could receive them only a whole week later in October; see Urkundenbuch (as in n. 5), 1:5-13, nos. 4-9; and again (one failing) in Acta (as in n. 2), 1:33-44, nos. 5-9. See especially Rexroth, Deutsche Universitätsstiftungen (as in n. 4), pp. 197-207. For the most important one also Jürgen Miethke, "Die Urkunde Ruprechts I. im Kontext der Heidelberger Universitätsgründung," in Eine neue Gründungsurkunde für die Universität Heidelberg, ed. Werner Moritz, Archiv und Museum der Universität Heidelberg. Schriften 8 (Heidelberg, 2005), pp. 9-23.
} 
lectures with a ceremonial feast a fortnight after the masters and students had obtained the privileges (October 19). We do not know how many students took part in the lectures given by two arts masters and one theologian, but we have to reckon it was a very small number of participants. Only four weeks later, the university succeeded in consolidating its community by electing the rector and freeing itself from the direction of the count's deputy. This relatively long interval is explained by the unfortunate fact that the masters had to wait for the arrival of a third magister artium before being able to celebrate the election. This was necessary because, in obvious similarity to the Parisian customs, only the Masters of Arts were allowed to elect the rector for the university, and in accordance with the Roman Law practice: tres faciunt collegium, ${ }^{10}$ i.e. the numeric minimum of an acting community had to be fulfilled before being allowed to perform elections. Significantly enough, there was - besides the three indispensable arts masters - one theologian present at the election, who was present in Heidelberg; but he was acting, so to speak, as an add-on, and was allowed to participate without establishing a precedent for the future. Obviously he was badly needed to fill out the appearance of the small group of electors. Besides, the result of the elections could not be of any surprise: Marsilius of Inghen, the count's special clerk, was now elected to become the first rector of the university. ${ }^{11}$ The one who had directed all efforts in the foundation process could now continue this activity in his new dignity. This may underline the predominantly symbolic character of these elections.

There were different means of strengthening the young institution, beginning with different kinds of written records for future memory - the rector started a list of matriculants, where in the first year of the existence of the university more than 500 persons were noted down and paid their matriculation fees. In addition, the rector began to write down all interesting or singular events as well as the forms of special letters, oaths or similar items in a special book. Therefore, we do know something about the actors. The creation of an individual seal for

\footnotetext{
${ }^{10}$ Dig. 50.16.85.

${ }^{11}$ For more on Marsilius, see Dagmar Drüll, ed., Heidelberger Gelehrtenlexikon, 13861651 (Heidelberg, 2002), pp. 373 ${ }^{\mathrm{a}}-374^{\mathrm{b}}$; Jürgen Miethke, "Marsilius von Inghen als Rektor der Universität Heidelberg," in Marsilius of Inghen, Acts of the International Marsilius of Inghen Symposium, eds. Henri A. G. Braakhuis, Maarten J. F. M. Hoenen, Artistarium, Suppl. 7 (Nijmegen, 1992), pp. 13-37. On Marsilius and his work see esp. Stanisław Wielgus, ed., Marsilius von Inghen, Werk aund Wirkung, Akten des 2. Internationalen Marsilius-von-Inghen-Kongresses (Lublin, 1993); and Maarten J. F. M. Hoenen and Paul J.J.M. Bakker, eds., Philosophie und Theologie des ausgehenden Mittelalters, Marsilius von Inghen und das Denken seiner Zeit (Leiden, 2000).
} 
the university, which was requested by the newly elected rector together with his electors, was immediately ordered by the count Palatine himself on November 18, only one day after the election of Marsilius of Inghen as rector. ${ }^{12}$ The seal as symbol of legal autonomy was the final cornerstone of the basic legal equipment of the institution. It does not seem that it was casually recorded by Marsilius because he continued to give attention to the special signs of the university's dignity. For instance, when he was elected about one year later to his second rectorate in December 1387, he allocated the rest of the money collected by several rectors for different purposes, especially for the first rotulus of supplications for the papal court and for a heavy mace for the whole university, ${ }^{13}$ a piece of goldsmith's craft whose basic structure remains to this day. ${ }^{14}$ Marsilius also founded the archive of the university at this time, when in February he ordered a chest as a container for the privileges of the university at his own expense. He writes happily that he succeeded in getting the seal of the city of Heidelberg in addition to the seals of the three Wittelsbach counts Palatinate on the most important foundation charter and placed the mace into the official care of each rector. $^{15}$

For ameliorating the financial status of the university masters the university soon decided to take over the method of supplication for ecclesiastical benefices at the papal court. This process was complicated somewhat by the Great Schism because it was supposed to be done only to the papal curia of the Roman obedience, which had the steady support of the Count Palatinate in those days. A rotulus was sent almost immediately after the foundation of the university. ${ }^{16}$

\footnotetext{
12 Acta 1:149-50, no. 74. For general reflections on the importance and use of seals in medieval society see Gabriela Signori (unter Mitarbeit von Gabriel Stoukalov-Pogodin), ed., Das Siegel. Gebrauch und Bedeutung (Darmstadt, 2007), see here especially Frank Rexroth, "Die universitären Schwurgenossenschaften und das Recht, ein Siegel zu führen, ” pp. 75-80.

13 Acta 1:169, no. 98: “virgam communem universitatis (...), que virga deaurata facta est et soluta ponderans in argento quinque marcas cum dimidia et mediam unciam, ascendens in universo computando medium florenum datum famulis pro bibalibus ad 56 florenos graves Renenses et duos solidos denariorum Argentinensium.” See generally also Jürgen Miethke, "Die Zepter der mittelalterlichen Universität als Audruck ihrer Verfassungsstruktur," in Mittelalterliche Universitätszepter, Meisterwerke europäischer Goldschmiedekunst der Gotik, ed. Johann Michael Fritz (Heidelberg, 1986), pp. 5-10.

${ }^{14}$ See, most recently, J. M. Fritz, "Heidelberg," Mittelalterliche Universitätszepter, pp. 16-17, no. 1, who argues convincingly by stylistic criteria for this early date of fabrication against the older literature.

${ }^{15}$ Acta 1:172-3, no. 103.

${ }^{16}$ Acta 1:12-14, no. 2: Nov. 19, 1389; cf. ibidem, 181, no.118. For the "system" of rotulus supplications see William J. Courtenay, ed., Rotuli Parisienses, Supplications to the Pope from the University of Paris, Education and Society in the Middle Ages and
} 
But this seemingly steady progress was not at all uniform. The political circumstances of the time impinged upon the life of university scholars as they did upon the citizens of Heidelberg. This became clear through many difficult circumstances. First, there was the dramatic situation of the church during the Great Schism, which had begun in 1378 and had, by this time, lasted for almost a decade. Heidelberg belonged to the "Urbanist" obedience, whereas Paris stood together with the French king and his court on the side of Clement VII, who had not only taken his residence in Avignon (after having tried in vain to repel Urban from Italy by military force) but was a near relative of the Valois family. The foundation of the Heidelberg university received a remarkable impetus from the Schism; it might not have come into being if there had not been German masters of Arts and Theology, who derived their income from German ecclesiastical benefices (i.e. mostly from "Urbanist" churches), and could not therefore stay in Clementist Paris without losing their fragile chances for preferment.

These problems brought to Heidelberg not only Marsilius of Inghen himself but also some other Paris-trained individuals, all of whom participated in these stormy beginnings. But the challenge of joining the right side in the schism controversy lasted well beyond the first steps of the university. Marsilius himself noted in his second rectorate (which lasted from December 1387 to March $1388^{17}$ ) that during the rectorate of his second predecessor, Johannes Berswort from Dortmund, ${ }^{18}$ the university had decided, seemingly after intensive debates, post plures congregationes (as it is verbally indicated), that in Heidelberg a distinction should be made between the graduates of Paris in respect to the schism: from all the badly needed masters and licentiates coming up

Renaissance 14 (Leiden, 2002), pp. 1-25; and idem, "John XXII and the University of Paris," in La vie culturelle, intellectuelle et scientifique à la cour des papes d'Avignon, ed. Jacqueline Hamesse, Textes et études du moyen âge 28 (Turnhout, 2006), pp. 23654. For the Heidelberg rotulus see Jürg Schmutz, "Erfolg oder Mißerfolg? Die Supplikenrotuli der Universitäten Köln und Heidelberg, 1389-1425 als Instrumente der Studienfinanzierung,” Zeitschrift für historische Forschung 23 (1996), 145-67.

${ }^{17}$ A chronological list of Heidelberg rectors is in Hermann Weisert, Dagmar Drüll, Eva Kritzer, eds., Rektoren - Dekane - Prorektoren - Kanzler - Vizekanzler Kaufmännische Direktoren des Klinikums der Universität Heidelberg, 1386-2006 (Heidelberg, 2007), here p. 1. The election is noticed in Acta 1:168, no. 96. The next election is not noted down in the Acta, but look at the Urkundenbuch (as in n. 5) 2:5, no. 40 [citing an entrance of June 21, 1388 on the balancing statement of Marsilius, noted down in Gustav Toepke, ed., Die Matrikel der Uiniversität Heidelberg, 7 vols. (Heidelberg, 1884), 1:27.

18 Elected in June 1387, Acta 1:162, no. 88. On him see Heidelberger Gelehrtenlexikon (as in n. 11), p. 279 . Obviously Berswort did not continue to write notes into the original "Rektorbuch"; Marsilius made up for this when succeeding him, as is clear from the wording of the entrance! 
from Paris to the newly founded higher school in Heidelberg, they did not want to admit any master or licentiate who had won his graduation with "Antichancellors or fictive chancellors, who had been nominated by the authority of the Antipope." 19 This massive setting aside of the famous licentia ubique docendi, which had adorned the ancient Alma mater of Paris for at least a century, was further topped by the attempt to get official papal consent for this procedure. When cardinal Philip of Alençon arrived as a papal legate in Heidelberg, ${ }^{20}$ in order to sign the first rotulus of supplications for benefices for the masters and to send a letter of recommendation for the rotulus (which was already on its way with the ambassador of the university), ${ }^{21}$ he was begged, again after intensive debates in several official congregations by the university, ${ }^{22}$ that the pope should declare by patent letters that the chancellor of Paris, who had received his office from the antipope, did not have the competence to confer degrees in any faculty. All those men graduated by him were not to be acknowledged as having graduated. The papal legate was to make sure that nobody of the Urbanist obedience could attend the University of Paris, in order not to give support to the antipope, whose authority might be strengthened by such graduations. But, unfortunately, Marsilius had to note a short time later that all the labors and costs invested in formal letters to the pope and his curia remained fruitless, because the legate did not want to pursue this bold attempt to rid from the Urbanist obedience the competition of the members of one of the oldest universities of Europe by the stroke of a pen and thereby supplant, so to speak, the old university of Paris by the new foundation of Heidelberg.

Very soon the Heidelberg masters had to encounter a new dramatic danger. Once again, we know this from Marsilius of Inghen who noted it twice in the book of matriculations. First, under the title of the immatriculations of his new rectorate where, after having added no less than 16 names of students for the last rector Berthold Suderdick, he had noted (and I translate): "Having not yet reached the middle of his rectorate, the rector, together with master Hartlevus de Marka and Dietrich (Kerkering) of Monastery and almost all the students, left Heidelberg because of the disease and the feuds of the time, while only a few remained. And in his place was substituted master Marsilius of

${ }^{19}$ Acta 1:167, no. 93: “...in dicta rectoria plures vocati magistri de universitate Parisiensi nobis advenerunt licenciati sub anthicancellariis vel pretensis cancellariis auctoritate antipape vel sibi adherentibus Parisius...”

${ }^{20}$ Acta 1:168, no. 96. See Gerhard Ritter, Die Heidelberger Universität im Mittelalter (1386-1508), Ein Stück deutscher Geschichte (Heidelberg, 1936; repr. Heidelberg 1986), pp. 261-62.

${ }^{21}$ Acta 1:169, no. 98.

${ }^{22}$ Acta 1:171-72, no. 102. 
Inghen.” 23 (He then continued to note the matriculations of only two names for the rest of the three-month period.) Afterward, he noted in the margin of the same page: "Attention! Here is noted the departure of the rector together with almost all the students because of the disease and the feuds and because of the foundation of the University of Cologne.”24 Obviously the bulk of these travelers made up their mind to leave the difficulties of Heidelberg, when relatively nearby Cologne - then the biggest city of Germany - decided to open a new university of its own. The framework of favorable economic conditions at Cologne was attractive for all masters and students, especially if they came from cities and villages in the neighborhood of Cologne. The list of refugees alone is telling enough: besides the acting rector of Heidelberg, the arts scholar Berthold Suderdik from Osnabrück, ${ }^{25}$ Marsilius of Inghen specifically named Hartlevus de Marka ${ }^{26}$ who later on became the first rector of the University of Cologne and also Dietrich of Monastery. ${ }^{27}$ Along with them, Johann Berswort of Dortmund, who had held the third of the threemonth rectorates of Heidelberg only one year before, departed a short time later. ${ }^{28}$ It seems significant for the crisis of Heidelberg, that during the following year one other pillar of the early foundation history of Heidelberg followed his colleagues to Cologne: Reginald of Aulne, who had started his theological lectures on the very first day of official lectures at Heidelberg. ${ }^{29}$

We cannot dwell on a prosopographical research here. We shall neither look at graduation in Paris or Prague nor to the homelands of the refugees from Heidelberg to the metropolis of Cologne, which were

\footnotetext{
${ }^{23}$ Toepke, Matrikel (as in n. 17), 1:34: "Item citra medium rectorie recedente rectore propter epidemiam et guerras et una secum magistris Hartlevo de Marka et Theoderico de Monasterio et fere simul omnibus scholaribus, paucis in comparatione demptis. Substitutus fuit magister Marsilius de Inghen, et intitulati sunt sub eo in parte eiusdem rectorie sequentis..."

${ }^{24}$ Ibid: "Attende hic recessum rectoris propter epydemiam et guerras et fere omnium scolarium et erectionem studii Coloniensis."

${ }^{25}$ Drüll, Gelehrtenlexikon (as in n. 11), p. $40^{\mathrm{a}-\mathrm{b}}$.

${ }^{26}$ Erich Meuthen, Kölner Universitätsgeschichte, vol. I: Die Alte Universität, Kölner Universitätsgeschichte 1 (Cologne, 1988), pp. 57-58 with 466, notes 53-54. For his connections with Marsilius of Inghen, see Jürgen Miethke, "Autograph des Heidelberger Gründungsrektors Marsilius von Inghen: Lectura in Matheum," in Bibliotheca Palatina, eds., Elmar Mittler, Walter Berschin, et al., Katalog zur Ausstellung, Textband (Heidelberg, 1986), col. 43-45; Dorothea Walz, "Marsilius von Inghen als Schreiber und Büchersammler," in Marsilius von Inghen, Werk und Wirkung, Akten des II. Internationalen Marsilius-von-Inghen-Kongresses, ed. Stanisław Wielgus (Lublin, 1993), pp. 31-71, esp. pp. 35-36.

${ }^{27}$ Drüll, Gelehrtenlexikon, pp. $123^{\mathrm{b}}-124^{\mathrm{a}}$.

${ }^{28}$ Drüll, Gelehrtenlexikon, pp. $279^{\mathrm{b}}$.

${ }^{29}$ Drüll, Gelehrtenlexikon, pp. $466^{\mathrm{b}}-467^{\mathrm{a}}$.
} 
mostly situated nearer to the latter. ${ }^{30}$ This fact seems to be far more important than the place of graduation as a motive for their migration. In any case, the statistically low influx of matriculations, after the high numbers of matriculations in the very first year of the university, was extremely evident in Heidelberg. Marsilius of Inghen could only welcome five matriculating students in almost half a year (five months), whereas in the six weeks before there had been 16; in the three months before that (still in the beginning of the spring term) we find no fewer than 103 immatriculations, and in summer 1388 there were still 57 individuals. $^{31}$

The diminishing enrollment of new students was dramatic. We cannot rule out that the causes cited by Marsilius had a significant impact; namely, disease and guerrae (specifically those wars that the count Palatinate and princely allies fought against the towns and cities in the southwest of Germany). ${ }^{32}$ Certainly these feuds were disruptive for the inhabitants of Heidelberg and for those connected to the university. Living in a smaller town also meant that the problem was felt more intensively. It was even perhaps a miracle that Marsilius of Inghen, who had a prebend in Cologne of his own, ${ }^{33}$ stayed in Heidelberg and upheld the standards of university life against all unfavorable circumstances. Almost by himself, he continued to make the notes in the "Rektorbuch", ${ }^{34}$ continued the list of matriculations (also taking care to supplement the inscriptions omitted by Berthold Suderdick, the refugee

30 Some indications of this are in Rainer Christoph Schwinges, Deutsche Universitätsbesucher im 14. und 15. Jahrhundert, Studien zur Sozialgeschichte des Alten Reiches, Veröffentlichungen des Instituts für europäische Geschichte Mainz, Abteilung Universalgeschichte 123 / Beiträge zur Sozial- und Verfassungsgeschichte des Alten Reiches 6 (Stuttgart, 1986), pp. 231-34.

${ }^{31}$ Rector Heinrich of Angern (starting 19.3.1388) immatriculated 103 persons, rector Dietmar Schwerte (starting 23. 6. 1388) immatriculated 57: see Toepke, Matrikel (as in n. 17), 1:28-32 and 1:32-33. For these two rectors see Drüll, Gelehrtenlexikon, p. $210^{\mathrm{a}-\mathrm{b}}$; resp. pp. $118^{\mathrm{b}}-119^{\mathrm{a}}$.

32 The so-called “war of the cities” (Städtekrieg) was briefly described by Meinrad Schaab, Geschichte der Kurpfalz, vol. 1: Mittelalter, 2nd ed. (Stuttgart, 1995); see also Ludwig Häusser, Geschichte der Rheinischen Pfalz nach ihren politischen, kirchlichen und literarischen Verhältnissen, 2 vols. (Heidelberg, 1856; repr. Speyer, 1978), 1:17984.

${ }^{33}$ Rexroth, Universitätsstiftungen (as in n. 4), p. 192. The university of Heidelberg knew this well: see Toepke, Matrikel, 1:636; he is named in the memorial notice in the Calendar of the Arts faculty: "Marsilius de Inghen canonicus sancti Andree Coloniensis et thesaurarius, fundator huius studij et initiator, in sacra theologia docctor egregius hic primus formatus ..."

34 This is evident from the overview of the authors of the entrances in a table drawn by Matthias Nuding in: Acta 1:630-34; see also the list of notes by Marsilius, ibidem, $1: 651$. 
to Cologne ${ }^{35}$ ), and seems to have been busy providing the university with a new and more solid financial base.

This was possible because of special circumstances, especially the succession of a new reigning prince in Heidelberg. Ruprecht $\mathrm{I}^{36}{ }^{36}$ the founder of the university, had died on the $19^{\text {th }}$ of February 1390, at the age of 81 years. His nephew and successor, Ruprecht II, ${ }^{37}$ was already 65 years old at this time. Ruprecht II was principally a military talent, and he had earned by his ruthless determination the nickname "Ruprecht the Hard (der Harte).” He had taken his subordinate position under his uncle unassumingly until coming into his own reign. He generally continued the lines of politics which his predecessor had drawn, but he was eager to do something of his own for the university, whose foundation charter he had sealed together with his uncle and his own son, who would succeed him in 1398. He tried in several respects to find enduring solutions for persistent problems. For the university this was a favorable and fortunate situation. Obviously, Marsilius was using every opportunity to stabilize the financial conditions of normal university life.

Hardly three months after his accession to government, Ruprecht II and Marsilius helped to execute the testament of Conrad of Gelnhausen, ${ }^{38}$ who had been the prepositus of the cathedral of Worms and therewith the first chancellor of the university. Without any doubt, Conrad had been one of the leading figures of church politics of the Palatinate. He died on April $13^{\text {th }}$ (1390) and had left almost all of his belongings to the university, including his admirable collection of books and manuscripts. Conrad had stipulated in his last will that his generous gift would be valid only if a collegium artistarum for 12 masters of arts would be constructed within two years, and he had carefully appointed as executors of his testament (besides others) the prince Ruprecht II himself and Marsilius of Inghen. ${ }^{39}$ We hear that this donation aimed ad

35 Toepke, Matrikel, 1:29 (note 17), 32 (note 2), 34 (note 4).

${ }^{36}$ Schaab, Geschichte der Kurpfalz (as in n. 32), 1:91-122; also see the essay by Jürgen Miethke, "Ruprecht I., der Gründer der Universität Heidelberg,” in Die Sechshundertjahrfeier der Ruprecht-Karls-Universität Heidelberg, ed. Eike Wolgast (Heidelberg, 1987), pp. 147-56.

37 Still informative is the article by Jakob Wille,"Ruprecht II., Pfalzgraf bei Rhein," Allgemeine Deutsche Biographie 29 (1889), 737-740; now see also Volker Rödel, "Ruprecht II," Neue deutsche Biographie 22 (2005), 289-90.

38 Drüll, Gelehrtenlexikon, pp. $91^{\mathrm{b}}-92^{\mathrm{b}}$; for his connexions to Bologna see Jürg Schmutz, Juristen für das Reich, Die deutschen Rechtsstudenten an der Universität Bologna, 1265-1425, Veröffentlichungen der Gesellschaft für Universitäts- und Wissenschaftsgeschichte 2 (Basel, 2000), pp. 181 and 389.

${ }^{39}$ A register of these mss. is noted down (already 1396) in: Toepke, Matrikel, 1:655-65, and later on (together with books from other sources) in the Rektorbuch, see Acta 1:466-513, nos. 453-69. 
erectionem collegii ad instar collegii Corbone Parisius. ${ }^{40}$ Whereas this seems to have been somewhat presumptuous, the executors indeed bought the necessary areas within the city less than four weeks after the death of the testator. ${ }^{41}$ And finally, in 1393 (June 24), the Count Palatine issued a charter of foundation for the College of Arts Students, adding new funds from tithes on the vineyards of Schriesheim (a village about five kilometers from Heidelberg down the Rhine valley) which was to remain a solid part of the revenues of the university until modern times. ${ }^{42}$ (This act of 1393 converted the originally private endowment of the Artists' College in Heidelberg into a princely one, almost like a foundation of state in the modern sense.)

Certainly the hand and the ideas of Marsilius are to be presumed behind this charter and its effects. We can support this assumption by looking at the next major consolidation of university finances, which came about in the same year 1390, the first year of Ruprecht II's reign. On the $10^{\text {th }}$ of August the prince declared that he had won by papal grace the commutation of his expensive vow to go on pilgrimage to the city of Rome for the Anno santo $1390 .{ }^{43}$ Ruprecht had sent a special embassy, which included Marsilius of Inghen, to the papal court which was busy with a rotulus of the university. On this occasion, he received (and certainly paid well for) a license allowing him to visit four churches within the Palatinate, which his confessor should assign to him, instead of the four papal basilicas in the Holy City. This license further granted him the same indulgences that were promised to the pilgrims for the

\footnotetext{
${ }^{40}$ Kalender der Juristischen Fakultät to April 13: Acta 1:14-32, no. 3, here 19.

${ }^{41}$ Winkelmann, Urkundenbuch (as in n. 5), 1:49-50, no. 28. It seems unsurprising to me that the realization of a collegium artistarum in Heidelberg had to wait far longer than the two years Conrad had reckoned with, but his bequest was the deciding and longstanding motivation for all the efforts concerning a Collegium artistarum in Heidelberg. See Wolfgang Erik Wagner, Universitätsstift und Kollegium in Prag, Wien und Heidelberg, Europa im Mittelalter 2 (Berlin, 1999), pp. 208-11; before e.g. Ritter, Heidelberger Universität (as in n. 20), pp. 133-34. In 1410, in his report to the count Palatinate Louis III, the rector of the university Konrad of Soest mentions this donation in the following words (Acta I: 448-56, no. 446, here 451): "Item post defuncto illustri principe domino Ruperto preseniore non multo post obiit bone memorie venerabilis pater dominus Conradus de Geylnhusen prepositus Wormaciensis etc., qui dicte universitati multa bona legavit in libris, in bonis et multis clenodiis et in parata pecunia, et venditis clenodiis tandem de consilio serenissimi principis etc. domini nostri noviter defuncti empta fuit area 'hinder dem marckbronne' wulgariter dicta pro fundacione collegii, et fuit fundamentum usque ad supraterram deductum, prout hodie apparet (!!!).”

${ }_{42}$ Printed most recently by Wagner, Universitätsstift (as in n. 41), pp. 384-85, and in Acta (as in n. 2), 2:70-72.

${ }^{43}$ Winkelmann, Urkundenbuch, 1:50-51, no. 29; see also Ritter, Heidelberger Universität, pp. 133-34.
} 
Anno santo in Rome $1390 .^{44}$ This really was a special grace and one of the first of its type. The prince had only to pay the estimated travel costs for his journey to Rome ad pios usus. And he had identified the University of Heidelberg as one such "pious purpose," certainly not without the whisperings of Marsilius and of his confessor. Ruprecht promised to give to the university 3,000 £, which he succeeded later on in reducing to the sum of about $2000 £$. But in any case, the university was able to buy a rent from the steady flow of customs at the toll stations on the Rhine in Bacharach and Kaiserswerth, where the university continued to receive money until the eighteenth century. ${ }^{45}$

It seems evident that all this information from our sources points to the same fact, that the university had to be supported by the prince, especially for stabilizing its financial income, for it became obvious within the stormy first months and years that without such stabilization the new foundation would go astray and vanish. Marsilius seems to have realized this point clearly and he succeeded in guiding the efforts of the ruling prince in this very direction. Certainly, a financial reconstruction of the university could not be the sole and unique aim of Palatinate politics, but Marsilius succeeded in taking advantage of all measures which could help his main purpose. We cannot say with certainty who struggled together with him in this same direction; certainly there must have been some support from other masters at the university. But the only information we have received about these measures are notices which Marsilius himself has written down into the official records of the university. At the very least, we should be permitted to say that he was one of the leading figures who drove the university and the court of the princes in this very direction.

This estimation of Marsilius's important role can also be said of an oft-mentioned case in which the prince added another important piece to the material frame of the university and to the well-being of its members. This time it came at the expense of the Jews in Heidelberg and

\footnotetext{
${ }^{44}$ Acta 1:448-56, no. 446, here 451-52: "Item ipso Marsilio de curia redeunti portavit pro domino nostro genitore domini nostri regis graciam anni iubilei, sic quod idem dominus noster expensas, quas fecisset eundo Romam et redeundo ab ea cum sua comitiva converteret in pios usus iuxta informacionem et direccionem sui confessoris. Item postquam hec gracia innotuit dicto domino nostro, ipse gratus et multum bene contentus ad hoc, ut esset capax indulgenciarum huiusmodi anni iubilei de consilio et direccione confessoris dedit pecunias certas ad universitatem ..."

${ }^{45}$ Markus Vetter, "Zur Finanzierung der Universität Heidelberg im Mittelalter, Die Einnahmen aus den Rheinzöllen in Bacharach und Kaiserswerth bis zum Ende des 15. Jahrhunderts," Ruperto Carola, Heidelberger Universitätshefte 78 (1988), 59-66; Gerhard Merkel, Wirtschaftsgeschichte der Universität Heidelberg im 18. Jahrhundert, Veröffentlichungen der Kommission für Geschichtliche Landeskunde in BadenWürttemberg, B.73 (Stuttgart, 1973).
} 
the Palatinate. To understand this case, we must first look briefly at the situation of the Jews in the later Middle Ages, especially in the Palatinate. The general situation of medieval minority groups was growing more and more difficult in connection with the general streamlining of societies on their way to modern statecraft. In the early Middle Ages, the whole society was built up, so to speak, by different minorities which together formed the larger structures of the early kingdoms. Within these complex structures the Jewish minority group, too, could live subjected to a law which was appropriate to foreigners. The Jews lived quite similarly to merchants (and indeed were, often enough, merchants themselves) who had to travel far away on their journeys. In this respect the Jews had a bearable, though not a comfortable, status within the tiny agglomerations of the early cities and townships. With the growing discipline and intensification of power structures in the "second age of feudalism" (to use the classification of Marc Bloch), that is, since the eleventh century, and especially in the twelfth and thirteenth centuries, their legal status deteriorated. In Germany we see the emergence of the so-called Kammerknechtschaft (that is to say, the "serfdom of the ruler's chamber"), ${ }^{46}$ but very similar structures were also developed in the western European kingdoms of France, England and the Iberian peninsula. ${ }^{47}$

Since the thirteenth century, the question arose in all European countries of who had the right - and the duty - to protect this minority group, because the possessor of that right could use them and their property for his own sake. Protection and exploitation were going increasingly hand in hand. These two relations are not easy to distinguish. The protector held all the belongings of the protected at his

\footnotetext{
${ }^{46}$ Friedrich Battenberg, "Des Kaisers Kammerknechte, Gedanken zur rechtlich-sozialen Situation der Juden im Spätmittelalter und früher Neuzeit,” Historische Zeitschrift 245 (1987), 545-99.

${ }^{47}$ The literature is immense, but it may be sufficient here to mention Alexander Patschovsky, "Das Rechtsverhältnis der Juden zum deutschen König (9. bis 14. Jahrhundert), Ein europäischer Vergleich,” Zeitschrift der Savigny-Stiftung für Rechtsgeschichte, germanistische Abt. 110 (1993), 331-71 (also available on the Internet: <http://www.uni-constanz.de/FuF/Philo/Geschichte/Patschovsky/aufsaetze/ index.html >, nr. XXI [16.04.2008]), where there is to be found rich source material for the European situation. For Germany alone see Peter Aufgebauer and Ernst Schubert, "Königtum und Juden im deutschen Spätmittelalter," in Spannungen und Widersprüche, Gedenkschrift für František Graus, eds. Susanna Burghartz and Hans-Jörg Gilomen (usw.) (Sigmaringen, 1992), pp. 273-314; an excellent summary of the German sitution is found in Dietmar Willoweit, "Die Rechtstellung der Juden," in Germania Judaica, vol. 3: 1350-1519, part 3: Gebietsartikel, Einleitungsartikel und Indices, eds. Arye Maimon (s.A.), Mordechai Breuer and Yacov Guggenheim, Veröffentlichungen des Leo Baeck Instituts 3.3 (Tübingen, 2003), pp. 2165-2207.
} 
disposition; he could even take away all their belongings, give away their property and eliminate their rightful claims. In the case of money lending he could decide to abolish, or lower at his own discretion, the interest of the debtors who had borrowed money from those under his protection at a certain rate of mortgage. This lowering or giving up of interests was an often-used instrument in the later Middle Ages, a sort of governmental burning of private debts, which could give immediate relief to favored groups. These were mostly done on behalf of those from the lower ranks of society, but also to those of noble stock who had gone deeper and deeper into debt, so that releasing debts altogether by one stroke was a very welcome relief, especially as the percentage of interests was normally extremely high (between 20 to 60 percent per year). Therefore we can observe the repeated occurrence of such measures of releasing debts and interests almost everywhere in the later Middle Ages.

But this situation throughout Europe had sad consequences, especially for the Jewish minority which was dependent for their wellbeing and safety upon the decisions of the rulers, who of course did not all view their responsibilities towards the Jewish people in the same way. In the different European communities, at different times and in different individual circumstances, an application of the Christian polemic together with the traditional critique of usury against the Jewish moneylending had disastrous consequences; ${ }^{48}$ for instance, during the first, second and third crusades in France, Germany and England, during the so-called black death around 1348/1349, and during other catastrophes and famines. In all of these catastrophic experiences we can observe devastating persecutions against the Jewish groups, families and quarters of those living in European cities. The rulers did not all fulfill their duty to protect the Jews, who could be devastated and exterminated by ruthless mobs, or at least expelled from the cities and villages. Other times, rulers handled the Jewish communities like their own personal belongings, giving them away or pledging them to foreign competitive money lenders (like the Lombards or Kawerschen, i.e. merchants and bankers from Northern Italy or Southern France). And the princes taxed their protégés at their own discretion, charging high fees for protection and allowances. Finally, some of the rulers, following the anti-Jewish polemics of zealous Christian clerics, gave the problem a seemingly final solution by deciding to expel the Jews completely from their territory if

\footnotetext{
${ }^{48}$ To cite only one example from a rich bibliography pertaining to the fourteenth century (with a focus on the polemics, not the expulsions), see Manuela Niesner, "Wer mit juden well disputiren", Deutschsprachige Adversus-Judaeos-Literatur des 14. Jahrhunderts, Münchener Texte und Untersuchungen zur deutschen Literatur des Mittelalters 128 (Tübingen, 2005).
} 
they did not want to convert to Christianity. Constrained baptism and constrained confession of the Christian faith was the order of the day for a long time. $^{49}$

We can observe such politics of expulsion almost everywhere throughout western Europe and in Germany. The kings of France and of England took this means as a "solution" for problems soon into the thirteenth and early fourteenth centuries. ${ }^{50}$ In Spain, even at the end of the Middle Ages - in the last years of the fifteenth century - a great expulsion was performed. In Germany there was no general policy from the king of the Romans or the Roman Emperors (when there was one), as the emperor had lost a considerable degree of his power to protect the Jews to local and regional princes and the cities. In the middle of the fourteenth century, the emperor Charles IV abandoned the politics of protection which his predecessor Louis the Bavarian had followed and made some terrible business transactions regarding the servants of "his" chamber (Kammerknechte), which he did not protect against real or planned attempts of devastation by their fellow citizens or rural mobs. ${ }^{51}$ Without going into the details of these sad stories here, it may be sufficient to remember that in Germany, too, there was a widespread tendency to expel Jews from various territories. But there was no unified or coordinated effort. Individual actions were unevenly distributed. This was of some help to the victims of these expulsions, as they could flee into neighboring territories, often quite close by. The count Palatine did not at first directly participate in these practices. ${ }^{52}$ Quite to the contrary,

\footnotetext{
${ }^{49}$ Still valid is the overview given by Peter Browe S.J., Die Judenmission im Mittelalter und die Päpste, Miscellanea historiae pontificiae 6 (Rome, 1942; repr., with preface by Bernhard Blumenkranz, 1973). A general overview is Peter Moraw, "Die Kirche und die Juden," Germania Judaica 3.3 (as in n. 47), pp. 2282-97.

${ }^{50}$ For France see William Chester Jordan, The French Monarchy and the Jews from Philip Augustus to the last Capetians, The Middle Ages series, (Philadelphia, 1989); for Germany see Michael Toch, Die Juden im mittelalterlichen Reich, Enzyklopädie deutscher Geschichte 44 (Munich, 1998); for England see Robin R. Mundill, England's Jewish Solution, Experiment and Expulsion, 1262 - 1290, Cambridge studies in medieval life and thought 4.37 (Cambridge, 1998).

${ }^{51}$ See Wolfgang Stromer von Reichenbach, "Die Metropole im Aufstand gegen König Karl IV. Nürnberg zwischen Wittelsbach und Luxemburg Juni 1348 - September 1349,” Mitteilungen des Vereins für die Geschichte der Stadt Nürnberg 65 (1978), 55-90; František Graus, Pest - Geisler - Judenmorde, Das 14. Jahrhundert als Krisenzeit, Veröffentlichungen des Max-Planck-Instituts für Geschichte 86 (Göttingen, 1987).

${ }^{52}$ A short and comprehensive view is in Wilhelm Volkert and Renate Höpfinger, "Kurpfalz," Germania Judaica 3.3 (as in n. 47), pp. 1919-35; a synthetic view of all of Germany is Michael Toch, "Die Verfolgungen des Spätmittelalters,"Germania Judaica 3.3: 2298-2327; see also Franz-Josef Ziwes, Studien zur Geschichte der Juden im mittleren Rheingebiet während des hohen und späten Mittelalters, Forschungen zur Geschichte der Juden A.1 (Hannover, 1995).
} 
Ruprecht I managed to open his land as a sort of shelter for Jewish refugees from his neighbors. ${ }^{53} \mathrm{He}$ also succeeded in gaining economic advantage from this, since he profited from the considerable fees that refugees were obliged to pay into the count's coffers. Very shortly after the disaster of the Black Death and the concomitant persecution, which had taken place in Heidelberg as well, he bought the taxes of the Jews from the emperor for six years (for the lump sum of $2000 \mathrm{lb}$. of pennies). Therefore he was obviously interested in protecting them, as he could tax them only when they remained where they were. But Ruprecht I continued with this policy over the years and tried to create a stable framework for Jewish business. For instance, in 1355, and again in 1371, he forbade taking interests higher than 1 to 2 pence a week for a lb. of pennies (more than 23 or $46 \%$ a year!!!). ${ }^{54}$

We must now consider the real numbers. Jews were not very numerous in the Palatinate then. In 1381 there were only 32 taxpayers in 10 localities in the Palatinate on the right side of the Rhine, 14 of them in Heidelberg, 4 nearby in Ladenburg, and 3 in Weinheim (about $20 \mathrm{~km}$ away). ${ }^{55}$ Ruprecht I indeed gained real advantages from being on good terms with powerful Jewish moneylenders, who lived for instance in his residential city of Heidelberg. ${ }^{56}$ The university seems not to have been interested in local confrontation, for in the first general statutes for the students, established in summer 1387 (formulated during the very first year of its existence) it is said, that "no student of our university shall offend by deed or word the belongings or the persons of any citizen or of any Jew, on penalty of 1 florin payable to the university and of incarceration..." 57

When Ruprecht I died, his nephew and successor Ruprecht II decided to follow quite a different path. We do not know the circumstances of his politics and we do not hear of his advisors or their arguments for the change in attitudes, but we see the prince following the examples of his neighbors in expelling the Jews from the Palatinate. Already in the year 1390, the very first year of his reign, he must have decided to expel the Jews from his country. ${ }^{58}$

\footnotetext{
${ }^{53}$ Ritter, Heidelberger Universität (as in n. 20), pp. 135-36.

${ }^{54}$ Germania Judaica (as in n. 46) 3.3:1921, with notes 17 and 18.

${ }^{55}$ Germania Judaica 3.3:1920.

${ }^{56}$ Germania Judaica 3.1:1922.

${ }^{57}$ Acta 1:163-64, no. 89, here 164: "Item fuit statutum concorditer, quod nullus scolaris studii nostri forefaceret verbo vel facto in rebus vel in persona cuicumque civi nec eciam cuicumque Iudeo sup pena unius floreni universitati applicandi, et carceris, si factum adeo esset enorme, quod faciens carceris pena merito deberet plecti."

${ }^{58}$ For the dating of the decision to the year 1390 see Ziwes, Studien (as in n. 52), pp. 253-54; 1391 was the date given by Wilhelm Volkert, "Die Juden in der Oberpfalz im
} 
The university very soon reacted to this - and this seems to be the first record we have of this whole event. A congregation of the masters discussed on November 2, 1390, whether it would be useful at that time to transform the houses and the synagogue, which were "assigned by the prince to the university after the expulsion of the Jews," for the planned Collegium artistarum and to stop therefore the works outside the wall which had already begun. ${ }^{59}$ We are told this by Marsilius himself, who noted down the minutes of this congregation in the Rektorbuch during his sixth rectorate. ${ }^{60}$ The masters decided in the end to do this, but to be careful not to raise the prince's question regarding money from the university in compensation for the houses of the Jews. We hear very soon, already by December 26, 1390, that the former synagoge of the Jews was transformed into a chapel and dedicated to Mary by the bishop Eckhard of Worms. ${ }^{61}$

Obviously the expulsion of the Jews from the Palatinate was seen by Marsilius as a welcome chance to foster the material framework of the university (or, to be more precise, the material framework of the university masters) for the future. He, and at least the majority of the masters, did not care about the former inhabitants of the houses assigned to them by the prince. They tell us nothing about the destination of the Jews or their paths to foreign lands. Even the date of the expulsion remains an open question. ${ }^{62}$ Only the houses of the Jews and the movable goods left by them were of interest to them. We have several notes in the Rektorbuch, mainly written down by Marsilius, tracking the financial consequences. Almost 20 years later, in 1410, we read in a report on the financial status of the university made for the grandson of Ruprecht II,

14. Jahrhundert, Zeitschrift für Bayerische Landesgeschichte 30 (1967), 161-200, here 186-87.

${ }^{59}$ See above, n. 41.

${ }^{60}$ Acta, 1:185-86, no. 124 [1390 XI 5]: “...quia tunc Iudeis expulsis domus eorum fuerunt cum synagoga universitati per principes nostros assignate, fuit propositum an expediret quod de illis domibus institueretur collegium universitatis et supersederetur de domo incepta extra muros opidi Heydelbergensis et quod restans pecunia converteretur in redditus pro magistris collegiandis et pecunia soluta pro domo lignea in istarum domorum reparacionem converteretur, videlicet 200ti floreni. (...) Super primo dictum fuit quod sic, sed quod hoc tractaretur subtiliter, ne per emulos studii suggeretur domibus ducibus restantes pecunias recipi ab universitate pro domibus Iudeorum sibi assignatis.”

${ }^{61}$ Acta, 1:11-2, no. 1; almost the same entrance is written down in connection to the (I.) calendar of the university, see Toepke, Matrikel 1:647-48. Later on (by the Rotulus of 1401) it was supplicated that the "capella beate Marie virginis in Heydelberg Wormaciensis diocesis, que est capella universitatis predicte" should be exempt from the bishops and chapters of Mainz and Worms (Acta, 1:141-43, no. 69, here 142-43), but this supplication was not signed by the pope.

${ }^{62}$ Ziwes, Studien (as in n. 52), p. 253-54. 
Louis III, which was formulated shortly after the death of Ruprecht's son and heir, the King of the Romans Ruprecht (III, as count Palatinate), some short remarks on the houses of the Jews and on their books, which were sold for a good sum of money (qui fuerunt venditi, et bona summa pecuniarum provenit). ${ }^{63}$ As usual, here too the only purpose of the notice was to secure the property of the university in the houses and the belongings left by the Jews expelled.

As for the motives, we hear nothing at all. We do not know the feelings of the university masters, or of Marsilius. However, when on August 1, 1401 the Roman king Ruprecht III (the son and successor of Ruprecht II) received an oath from his two sons regarding who should succeed him afterwards and care for the university during their reign, he had them specify by oath "daz eweclich kein Jude oder Judinnen in slossen und landen der Phalz und herczogthoms obgenant wonen, sesshaftig oder blibehaftig sin sal (i.e. "that in perpetuity no Jew, man or woman, shall be allowed to stay, to live or to remain in the Palatinate")." 64 It was here that we do find a sort of motivation for that policy: the presence of Jews will cause "merklich schade geistlich und werntlich, (...) maniche sundige sachen und wehe, (...) wucher und anders daz Juden und Judinnen als offentlich under den Cristen wonend, wandernt und gemeinschaft mit yn hant," to be brought into the country (i.e. "many sins and harm, ... usury and other evils, which Jewish men and women, who live publicly in Christian neighbourhoods, or migrate there and have community with them, bring"). ${ }^{65}$ This is only a very

\footnotetext{
${ }^{63}$ The famous report, delivered by the rector Konrad of Soest at the Castle to the new count Palatinate, is now edited in: Acta, 1:448-56, no. 446, here 451: "Item ex post tempore illustris principis domini Ruperti senioris genitoris domini nostri regis, expulsis Iudeis, matura deliberacione prehabita ad providendum universitati de congruis habitacionibus domos Iudeorum universitati donavit, prout ex litteris donacionis clare constat. Item donavit eidem libros Iudeorum, qui fuerunt venditi, et bona summa pecuniarum provenit..." The report continues by mentioning the great expenses in repairing and restructuring the houses "et fuerunt notabiles et magne pecunie exposite." Marsilius himself had written expressly propria manu that the university had a considerable sum of money. See Acta, 1:203-07, no. 156, here 205: "de pecuniis quas recepit universitas de libris sibis ad collegium assignatis sumptis in expulsione Iudeorum.”

${ }^{64}$ Cited after Ziwes, Studien, p. 173, n. 368; already transcribed by Leopold Löwenstein, Beiträge zur Geschichte der Juden in Deutschland, Bd. I: Geschichte der Juden in der Kurpfalz, (Frankfurt am Main, 1895), p. 19; a short "regest" also in: Regesten der Pfalzgrafen bei Rhein, vol. II: 1400-1410, ed. Graf L. von Oberndorff (Innsbruck, 1939), no. 1246.

${ }^{65}$ Cited after Germania Judaica (as in n. 47), 3.3:1928 and 1934, n. 91; a "regest," i.e. a short description (not the wording) of the oath already in Karl Heinrich von Lang, Maximilian Prokop von Freyberg and Georg Thomas Rudhard, eds., Regesta sive rerum Boicarum autographa ad annum usque MCCC: e regni scriniis fideliter in summas
} 
shadowy hint of the ideas which were common to Christian people in those times. We cannot see what more specific ideas were developed to motivate the policy of expulsion in Heidelberg.

At any rate, Ruprecht II issued a great charter on May 21, 1391, ${ }^{66}$ which certified the transfer of property of the former Jewish houses to the university which received by this means a steady and fixed quarter within Heidelberg. ${ }^{67}$ The university profited greatly from these measures, which banned the Jews from the Palatinate (certainly not forever, but for many years to come). But we do not have space to follow up the history of Jewish living in Germany here. The University of Heidelberg seems to have finally obtained by all these means sufficient formal and material security to help it resist future calamities. In 2011, the $625^{\text {th }}$ anniversary of the university will be celebrated, and to be sure, it will be feasted with all the solemnity an "excellent” German university can afford.

It certainly was not for the sake of these advantages (at least not for these alone), that the university was interested in the policy of the prince Palatinate against the Jews. It seems to me remarkable that in Germany the foundation of universities gave a certain impulse to persecution and expulsion of Jews in the same manner as it gave impulses for persecuting heretics. There were several instances for driving Jews out of the city and from the territory when a new university was founded. In the later fifteenth century we can see it at the University of Tübingen, where in 1477 a university was founded. In this very year the Jews were driven from the town, and the university played an active part in these procedures. Similar phenomena can also be observed in Freiburg im Breisgau a little later (1502). ${ }^{68}$ We could also add the persecution of Jews in Vienna in 1419 where the university took an

contracta iuxtaque genuinam terrae stirpisque diversitatem in Bavarica, Alemanica et Franconica synchronistice disposita 11 = Continuatio 7 (Munich, 1847), p. 219. Very similar is the motivation given in the famous so called "Ruppertinian Constitution" (13. July 1395), where Ruprecht II has given a comprehensive statute for his lands, cf. Meinrad Schaab, Rüdiger Lenz, eds., Ausgewählte Urkunden zur Territorialgeschichte der Kurpfalz, 1156-1505, Veröffentlichungen der Kommission für Geschichtliche Landeskunde in Baden Württemberg A.41 (Stuttgart, 1998), pp. 150-64, no. 93, here 159:§19: “...<Wir $>$ sin auch underwieset, daz wir die juden, umb daz sie wuchergut hant, nit halten mogen mit unsir selenheile, darumb so seczen wir zu selegerede fur uns und unsir erben [...] daz wir und unsere erben furbas mee keinen juden oder kauwerzen, die man nennet lamperter, husen halten oder haben sollen in unsern sloßen und landen, umb daz sie offenen wucherer sin und daz lant von teglichem wucher und schaden davon verderplich wirt und daz wir sie unser seleheile nit gehalten mogen.”

${ }^{66}$ Urkundenbuch (as in n. 5) 1:51-53, no. 30.

${ }^{67}$ Ritter, Heidelberger Universität, pp. 135-39; Andreas K. Vetter, “Die topographische Entwicklung der Universität Heidelberg im Mittelalter,” Ruperto Carola, Heidelberger Universitätshefte 85 (1992), 87-98.

${ }^{68}$ Willoweit, "Rechtsstellung” (as in n. 47), 2205-06. 
active part in the expulsion of Jews. ${ }^{69}$ In this city the debates on the Jewish citizens were especially intensive, as several treatises confirm. ${ }^{70}$

I want to add here some examples of the persecution of heretics, which seems to have been intensified immediately after university masters of theology were available in the region. I mention here only the Heidelberg situation: already in 1390, when debating the question of whether the houses of the Jews assigned by the prince to the university should be used for the Collegium artistarum, the masters felt it necessary to give their opinion on the strange phenomenon that they had heard about from their fellow citizens, namely that a group of flagellants had been seen near the town on the mountain "Heiligenberg." 71 The masters discussed this topic and decided to take part "by all means against those" and would write down a memorandum for the princes who should forbid them because of the dangers which they could arouse. ${ }^{72}$ Obviously they meant heretical deviation, which they wanted to eliminate by all means, including the then normal procedure of burning heretics. Only two years later there took place a somber ceremony in Speyer, the nearby city of a bishop, where several Heidelberg masters had their benefices and later on some benefices of the Heilig-Geist-Stift of the university were situated. Here three clerics in higher ranks of the episcopal clercs were condemned as heretics. Two of them were certainly burned and the last one, who seems to have abjured his errors, was condemned ad perpetuos carceres in pane doloris et aqua angustie. ${ }^{73}$ Later on at the council of Constance, Heidelberg masters of theology took part in the trial against Jan Hus and Jerome of Prague, both of whom were burned as heretics. ${ }^{74}$ And in the third decade of the fifteenth century, the Heidelberg masters of theology

\footnotetext{
${ }^{69}$ Michael H. Shank, Unless you believe, you shall not understand: Logic, University, and Society in Late Medieval Vienna (Princeton, 1988).

${ }^{70}$ Manuela Niesner, "Über die Duldung der Juden in der christlichen Gesellschaft Eine lateinisch-deutsche Quaestio aus der Zeit um 1400,” Mediaevistik 20 (2007), 185214; see also Niesner, "Wer mit juden will disputirn” (as in n. 48), passim.

${ }^{71}$ This movement of laicists has won a great attention in modern research. Here I want to cite only Graus, Pest - Geißler - Judenmorde (as in n. 51), look at the Index, 603 ${ }^{\mathrm{a}}$; succinctly Neithart Bulst, "Flagellanten (Geißler, Flegler) II. Gebiete nördlich der Alpen,” Lexikon des Mittelalters 4 (1989), 510-12.

72 See above note 60. Here, see Acta, 1:186: "Quintus [punctus] quia in monte omnium sanctorum fuerunt visi flagellatores die omnium sanctorum, quid super hoc esset agendum. ... Super quinto, quod universitas omni modo se illis contraponeret et principibus et civitatibus scriberet de prohibicione eorum et ut ducibus insinuaret pericula, que de illis et huiusmodi sectis possent emanare.”

73 This is the wording in a contemporary notice made in the calendar of the Lawyers' faculty, Acta 1:29-30 (printed also in Toepke, Matrikel, 1:647-48).

${ }^{74}$ For the process against Hus, the most comprehensive study is now Jiř́ Kejřr, Die 'Causa' Johannes Hus und das Prozessrecht der Kirche, trans. Walter Annuß (Regensburg, 2005), who does not go into details on the Heidelberg participants.
} 
were most keenly interested as inquisitors against Hussite heresy. Heidelberg thus had a leading role in this respect throughout all of Germany - several Hussite heretics were burnt in Heidelberg on the judgment of a learned commission, where several Heidelberg professors had taken part. ${ }^{75}$ Protestant theologians, and Luther himself, have acknowledged some of these Hussites as forerunners of the reformation of the sixteenth century.

It seems evident to me that the existence of a university had farreaching consequences for its surrounding society. Learning interesting information and acquiring new knowledge were not the only possibilities introduced by this new institution in the territory of the prince. The precision and exactitude of controllable notions could also evoke the idea of strictly eliminating all deviance from the path of virtue. The authorities felt strongly enough to see the right and the wrong in any behavior. I think that this is the connection between the foundation of universities and the increasing persecution of minority groups, that is to say not a specific doctrine (like the theology of trinity ${ }^{76}$ ) or the motives of some leading figures of the faculties, but rather the mere existence of a university where such institutions of higher learning had not existed before. This effect of founding a new university was unavoidable in any case.

We must stop here. We cannot explain entirely the decisions made in Heidelberg at the end of the fourteenth century. We can only follow up step by step the single events which we know from our scattered sources. We cannot get a very vivid picture, but we see enough to be sure, that the founding of a university had, at least in this case (and we may add: as in others), two sides. Heidelberg is telling us the doublesided story of difficulties in founding universities in Germany in the later Middle Ages. The economic problems could only be solved by a steady and energetic aid from political authorities who had to initiate the foundation and had to continue their efforts in supporting the new

\footnotetext{
${ }^{75}$ Hermann Heimpel, Zwei Wormser Inquisitionen aus den Jahren 1421 und 1422 hrsg. und erläutert, Abhandlungen der Akademie der Wissenschaften zu Göttingen, Philologisch-Historische Klasse III/73 (Göttingen, 1969); idem, Drei InquisitionsVerfahren aus dem Jahre 1425, Akten der Prozesse gegen die deutschen Hussiten Johannes Drändorf und Peter Turnau sowie gegen Drändorfs Diener Martin Borchard hrsg. und erläutert, Veröffentlichungen des Max-Planck-Instituts für Geschichte 24 (Göttingen, 1969). Heidelberg masters had an active role to play in all of these persecutions; without them the inquisitions would hardly have been made. See also Kurt-Victor Selge, "Heidelberger Ketzerprozesse in der Frühzeit der hussitischen Revolution,” Zeitschrfit für Kirchengeschichte 82 (1971), 167-202.

${ }^{76}$ Shank, Unless you believe (as in n. 69) has made this point. But I would not take this as a wholesome reason for the persecution of Jews.
} 
institution again and again. Processes of rationalization and of augmentation of knowledge are nowhere a simple task, and by no means can they be considered only as a positive event. This is an experience not only of our modern times, but of the Middle Ages as well. 